建材からの揮発性有機化合物の発生がス特性

環境条件による発生ガスへの影響に関する研究 その 1

\title{
CHARACTERISTICS OF VOLATILE ORGANIC COMPOUNDS EMISSIONS FROM SOLID BUILDING MATERIALS
}

Study on the effect of environmental conditions on emissions from materials Part 1

\author{
朴 俊 錫*, 藤 井修二** \\ Jun-seok PARK and Shuji FUJII
}

\begin{abstract}
Many sources of volatile organic compounds (VOC) including smoking, combustion and building materials have been identified in indoor environment from several studies. In this indoor VOC source, emissions from building materials have become current interests, and several methods to evaluate emissions from materials have been developed. Chamber test method is used to evaluate emission rate of compounds emitted from materials. But few have been made to comprehend the effect of environmental conditions on emission rates in chamber test. In this paper, emissions from three vinyl wallpapers and two gypsum boards were examined by several conditions of chamber. Compounds emitted from materials were analyzed and the influence on emissions rates by environmental conditions, such as temperature, relative humidity, ventilation rate and loading factor was evaluated. And it is found that emission rates of compounds are depended on environmental conditions, and the increasing of temperature, relative humidity and ventilation rate of the chamber accelerates emissions from the materials. Because the concentration difference of the chamber was not large under the experiment condition, the influence on emissions rates by loading factor could not be evaluated.
\end{abstract}

Keywords: indoor air quality, volatile organic compounds(VOC), building materials, emissions 室内空気質、揮発性有機化合物、建材、発生ガス

\section{1.はじめに}

筆者らは室内に多くの揮発性有機化合物 (volatile organic compounds、以下VOC) が $\mu \mathrm{g} / \mathrm{m}^{3}$ 以上の濃度で存在することや、これ らのVOCが外気由来だけではなく、室内にその発生源を有すること を前報1）で報告した。なお、アトリウムと住宅における実測調查よ り室内のVOC発生源には喫煙、植栽に使われる薬剤や建材からの発 生ガスなどがあることを明らかにし、室内VOCの污染制御を考える 上ではこれらの発生源に関する定性・定量的な評価が必要であるこ とを示した2）。

VOCの発生源のなかで特に建材からは多くの物質が発生し、その 発生ガスは室内VOC濃度に大きな影響を及ぼす2）。建材からの発生 ガスについては、海外では欧米を中心とした報告があり、例えば、 Molhave $ら^{3)}$ 、Nielsen $5^{4)}$ 、Wolkoff $5^{5)}$ Dunn $ら^{6)}$ 、Tichenor $5^{7)}$ による研究があげられる。DunnらとTichenorらはチャンバー実験よ り室内で使用される各種建材からの発生ガスについて報告し、発生 ガスの指数関数的挙動を基に内部拡散モデル、吸収モデルなどの発 生ガス簡易評価モデルを提案した。一方、国内では、鈴木ら ${ }^{8 ）, 9 ） ~}$ によりクリーンルームにおける内装材と構成材からの発生ガスに関 する研究が、また、池田ら 10)により新筑住宅における内装材から の発生ガスと室内VOC濃度に関する実測結果が報告されている。し
かし、これらの現象の原因とも言える発生ガスの物理的特性に関す る検討は少なく、室内に使用される建材からの発生ガスを定性・定 量評価するためには、まず建材が暴露される環境条件と発生ガスの 関係を把握する必要があるが、室内の温度、湿度、換気などの環境 因子による発生ガスへの影響については明確にされていない。

そこで本研究では、環境条件による建材からの発生ガスへの影響 を把握し、環境条件と発生量の関係について検討することを目的と した。以下では、一般建築空間でよく使われる 3 種類のビニール壁 紙と 2 種類の石靔ボードを対象に発生ガス評価実験を行い、発生ガ スの基礎的特性と温度、湿度、換気回数、ローディングファクター などの環境因子と発生ガスの関係について検討した。

\section{2. 実験概要}

\section{1 実験装置と対象建材}

建材からの発生ガス測定にはチャンバー実験を用いた。図 1 に実 験装置の概要を示す。実験はチャンバーの環境を調節するため、温 湿度および風量の制御が可能な人工気象室で行った。人工気象室内 にはステンレス製のチャンバー(内部容積 1.8 liter)、3つを並列 に並べ、各チャンバーには換気流量の制御のためにエアポンプを設 置した。チャンバーの換気は人工気象室より温湿度が制御された空
* 国立公衆衛生院建築衛生学部 研究員 · 工博

** 東京工業大学大学院情報理工学研究科情報環境尃攻 教授・工博
Researcher, Dept. Architectural Hygiene Engineering and Housing, Institute of Public Health, Dr. Eng.

Prof., Dept. Mechanical and Environmental Informatics, Graduate School of Information Science and Engineering, Tokyo Institute of Technology, Dr. Eng. 
気をVOC除去のための活性炭フィルタを通して行った。なお、実験 前にはトレーサーガス $\left(\mathrm{CO}_{2}\right)$ 法を用いてチャンバー内部が各実験条 件でほぼ完全拡散状態であることを確認した。

表 1 に実験対象建材と実験条件を示す。実験対象建材は一般建築 空間で壁材と天井材として使われているビニール壁紙 3 種類と石望 ボード 2 種類とした。各対象建材は市販のものであったため、製造 後の経過時間と流通過程における保存状態については夫知であった。

実験条件は温度と湿度、また、チャンバー内の気流とVOC濃度を 決める換気回数とローディングファクターとした。ローディング ファクターは、チャンバー容積に対する圾験体の面積比であり、換 気とともにチャンバー中のVOC濃度を決める因子の一つである。

実験では、まず全ての対象建材について発生ガスに関する基礎赛 験を行い、次に温湿度による発生ガスへの影響に関する実験(以下、 温湿度実験) と換気回数やローディングファクターなどのチャン バ一条件による発生ガスへの影響に関する実験（以下、チャンバー 条件実験)を行った。発生ガスの測定では人工気象室とチャンバー 内の環境が定常状態に達した後、試験体をチャンバーの底に平らに して置き、吸着材を充填したスチレン捕集管を用いて発生ガスのサ ンプリングを行った。サンプリングはチャンバーへの導入空気と排 気について実験開始後 $1,3,6,12,24,36$ 時間に行った。

\section{2 VOCの缚篮と分析方泫}

今回の実験では、前報2) と同様、ガスクロマトグラフィ(Gas Chromatography、以下GC) とガスクロマトグラフィ質量分析計 (GCMass Spectroscopy、以下GC-MS) から定性分析可能な、80-250 $\mathrm{C}$ まで の沸点を持つVOCを分析対象とした。表 2 はVOCの捕集方法と分析 条件を示す。VOCの吸着材としてはGCによる定量分析ではTenaxGC(60/80mesh、ジーエルサイエンス社)を、GC-MSによる定性分析 ではTenax-TA (20/35mesh、ジーエルサイエンス社)を用いた。

定性・定量分析では、GC-MSの分析から得られたマススペクトル により各ピークの成分を同定し、同定可能なVOCのみについて標準 試料で作成した検量線により定量分析を行った。なお、定量分析で は各実験条件における吸着材の捕集効率を測定し、補正を行った。 捕集効率は発生ガスをサンプリングする際にスチレン捕集管を直列 に2本をつないだ状態でサンプリングを行い、上流側と下流側それ ぞれの捕集量より求めた。総揮発性有機物質 (total volatile organic compounds，以下TVOC) 浱度についてはGCで得られたクロマトグラ フィの全面積をトルエン換算した濃度を用いた。

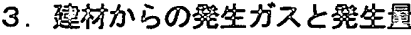

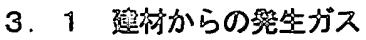

実験対象建材から発生するVOCとその基整的特性を把握するため に発生ガスに関する基礎実験を行った。基礎実験では全ての建材に つて温度 $20^{\circ} \mathrm{C}$ 、相対湿度 $60 \%$ 、換気回数 4 回 $/ \mathrm{h}$ 、ローディング ファクター $7.10 \mathrm{~m}^{-1}$ (石耪ボードの場合には $1.42 \mathrm{~m}^{-1}$ )の条件で発生ガ ス測定を行った。

図 2 はビニール壁紙と石虸ボードから発生したVOCのチャンバー 浪度を示す。各チャンバーでは試験体からの発生ガスのため、VOC 浱度が大きく増加するが、その濃度もチャンバーの換気によって減 衰していく。ビニール壁紙Aではジクロロベンゼンをはじめ、全て

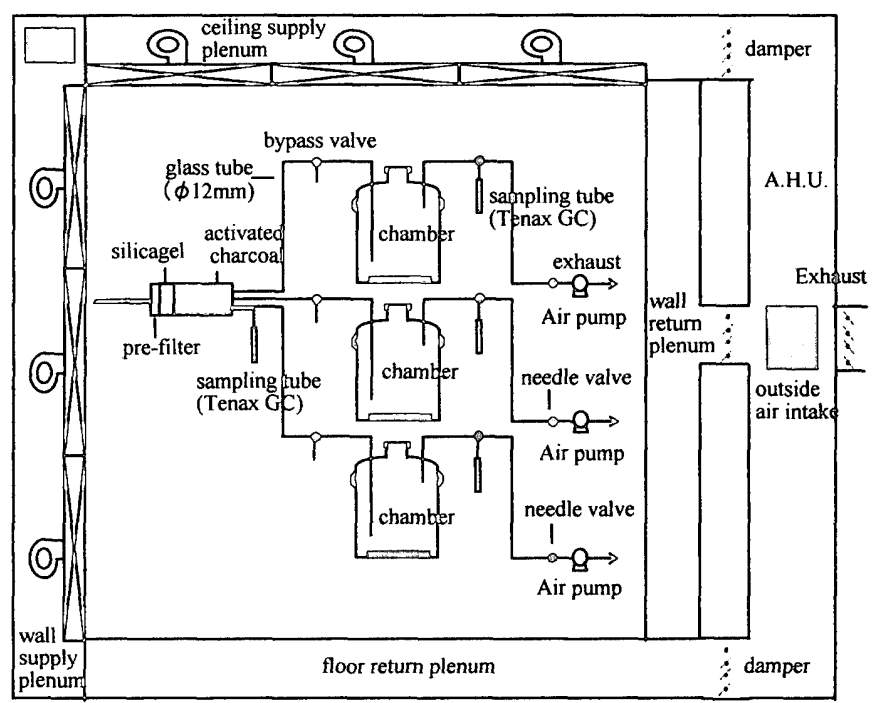

図 1 実験装置の概要

表 1 対象建材と実験条件（*：石驾ボード、L.F.: loading factor）

\begin{tabular}{|c|c|c|c|c|}
\hline \multirow[b]{2}{*}{ 実験内容と対象建材 } & \multicolumn{4}{|c|}{ 実験条件 } \\
\hline & $\begin{array}{l}{\left[{ }^{8} \text { 温度 }\right.} \\
{\left[{ }^{\circ} \mathrm{C}\right]}\end{array}$ & $\begin{array}{c}\text { 相驽湿度 } \\
{[\%]}\end{array}$ & 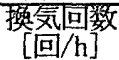 & $\begin{array}{l}\text { L.F. } \\
{[1 / \mathrm{m}]}\end{array}$ \\
\hline 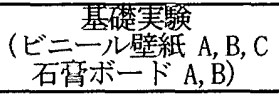 & 20 & 60 & 4 & $7.10(1.42) *$ \\
\hline \multirow{2}{*}{$\begin{array}{l}\text { 温湿度実験 } \\
\text { 石筲ボードーF） }\end{array}$} & $\begin{array}{l}20 \\
30 \\
40 \\
\end{array}$ & 60 & \multirow[b]{2}{*}{4} & \multirow{2}{*}{ 7. $10(1.42) *$} \\
\hline & 30 & $\begin{array}{l}50 \\
60 \\
70 \\
\end{array}$ & & \\
\hline \multirow{2}{*}{ 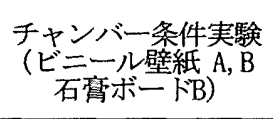 } & \multirow{2}{*}{20} & \multirow{2}{*}{60} & $\begin{array}{l}4 \\
6\end{array}$ & 7. $10(1.42) *$ \\
\hline & & & 4 & $\begin{array}{l}3.55(0.71) \\
7.10(1.42)\end{array}$ \\
\hline
\end{tabular}

\begin{tabular}{|c|c|c|}
\hline \multicolumn{3}{|c|}{ 捕集条件 } \\
\hline 捕集方法 & \multicolumn{2}{|c|}{ 常温吸着法 } \\
\hline 捕集凧 & \multicolumn{2}{|c|}{$\begin{array}{l}\mathrm{GC} \text { 分析角: Tenax-GC(60/80mesh, } 0.3 \mathrm{~g}) \\
\text { GC-MS 分析用 : Tenax-TA(20/35mesh, 0.1g }\end{array}$} \\
\hline 捕集量 & \multicolumn{2}{|c|}{5 liter $(1 \mathrm{liter} / \mathrm{min})$} \\
\hline \multicolumn{3}{|c|}{ 分析桑件 } \\
\hline 項 目 & GC & GC-MS \\
\hline 捕集営加鶖褞度 & $280^{\circ} \mathrm{C}(15 \mathrm{~min})$ & $250^{\circ} \mathrm{C}(15 \mathrm{~min})$ \\
\hline 検出器 & FID & $\begin{array}{l}\text { Quadrupole mass } \\
\text { spectrometer } \\
\text { EI Ionization }\end{array}$ \\
\hline キャリアカス & $\mathrm{N} 2(35 \mathrm{ml} / \mathrm{min})$ & $\mathrm{He}(2 \mathrm{ml} / \mathrm{min})$ \\
\hline $\begin{array}{c}\text { キャピラリー } \\
\text { カラム }\end{array}$ & $\begin{array}{c}\text { DB-1 } \\
30 \mathrm{~m} \times 0.53 \mathrm{mmID}\end{array}$ & $\begin{array}{c}\mathrm{NB}-1 \\
30 \mathrm{~m} \times 0.25 \mathrm{mmID}\end{array}$ \\
\hline カラムオーブン & \multicolumn{2}{|c|}{ 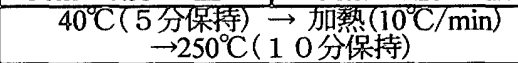 } \\
\hline
\end{tabular}

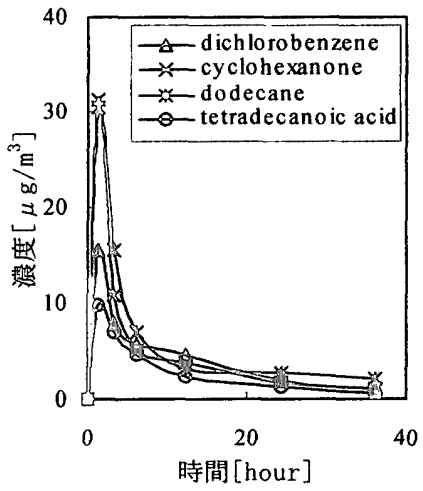

(a)ビニール壁紙 $A$

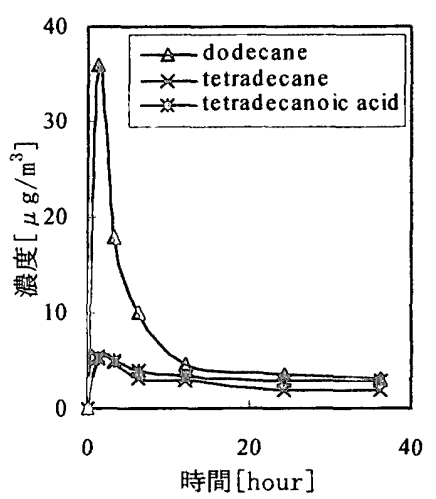

(b)石膏ボードA
図 2 チャンバー内の発生ガス濃度 
の発生ガスが実験開始直後には $10 \mu \mathrm{g} / \mathrm{m}^{3}$ 以上の濃度を示すが、36時 間後では $2 \mu \mathrm{g} / \mathrm{m}^{3}$ 以下となる。石育ボードにおいても各物質より濃度 差はあるが、チャンバー内のVOC濃度は初期に最も高く、実験開始 24時間後ではほぼ定常状態に達した。

表 3 は各対象建材からの発生ガスと簡易減衰モデル6)より求めた 初期発生量を示す。簡易減衰モデルでは建材からの発生ガスを(1) 式で近似し、図 2 に示したチャンバ一濃度と (2) 式の物質収支式を 用いて最小二乗法による非線型回帰分析より初期発生量を求めた。 ここで初期発生量は発生ガス初期におけるピーク発生量を、減衰定 数は発生量の一次減衰率を表わす。

$$
\begin{aligned}
& R(t)=R o \cdot \exp (-k \cdot t) \\
& \frac{d C}{d t}=\frac{S}{V} \cdot R(t)-\frac{Q}{V} \cdot(C-C o)
\end{aligned}
$$

ここで、 $R:$ 発生量 $\left[\mu \mathrm{g} / \mathrm{m}^{2} \cdot \mathrm{h}\right] 、 R o:$ 初期発生量 $\left[\mu \mathrm{g} / \mathrm{m}^{2} \cdot \mathrm{h}\right]$ 、

$k:$ 减衰定数 $[1 / \mathrm{h}] 、 t:$ 時間 $[\mathrm{h}] 、 V:$ チャンバー容積 $\left[\mathrm{m}^{3}\right]$ 、

$\mathrm{S}:$ 試験体面積 $\left[\mathrm{m}^{2}\right] 、 C:$ チャンバー内のVOC濃度 $\left[\mu \mathrm{g} / \mathrm{m}^{3}\right]$ 、 $Q:$ 換気量 $\left[\mathrm{m}^{3} / \mathrm{h}\right] 、 C o:$ 導入空気中のVOC濃度 $\left[\mu \mathrm{g} / \mathrm{m}^{3}\right]$

ビニール壁紙A、B、Cからは芳香族のジクロロベンゼン、トリメ チルベンゼン、エチルベンゼン、炭化水素のドデカン、テトラデカ ン、へキサデカン、カルボン酸のテトラデカン酸が、石弯ボードA、 Bでは炭化水素のドデカン、テトラデカン、カルボン酸のテトラデ カン酸などが発生した。ビニール壁紙Cでは他の建材よりも多くの 物質が発生し、ジクロロベンゼンの場合、 $255.2 \mu \mathrm{g} / \mathrm{m}^{2} \cdot \mathrm{h}$ の最も高 い初期発生量を示した。TVOCの初期発生量はビニール壁紙Cで $481.5 \mu \mathrm{g} / \mathrm{m}^{2} \cdot \mathrm{h}$ 、石育ボードA、Bで各々 $608.9 \mu \mathrm{g} / \mathrm{m}^{2} \cdot \mathrm{h} 、 64.4 \mu$ $\mathrm{g} / \mathrm{m}^{2} \cdot \mathrm{h}$ であった。このTVOCは同定されなかった物質も含まれた濃 度であり、各建材共に多くのVOCを発生していると考えられる。

\section{2 発生量}

図 3 はビニール壁紙と石高ボードにおける発生量の経時変化を示 す。発生量は(2) 式のチャンバー内物質収支式を用い、各サンプリ ング時刻における発生量を定常状態と仮定した(3)式より求めた。

$$
R=\frac{N}{L}(C-C o)
$$

ここで、 $R$ : 発生量 $\left[\mu \mathrm{g} / \mathrm{m}^{2} \cdot \mathrm{h}\right] 、 N:$ 換気回数 $[$ 回 $/ \mathrm{h}](N=Q / V)$ 、

$$
L: \text { ローディングファクター }\left[\mathrm{m}^{-1}\right] \quad(L=S / V)
$$

ビニール壁紙Aでは実験開始 1 時間後、ジクロロベンゼンが $8.9 \mu$ $\mathrm{g} / \mathrm{m}^{2} \cdot \mathrm{h} 、$ シクロヘキサンノンが $17.8 \mu \mathrm{g} / \mathrm{m}^{2} \cdot \mathrm{h}$ 、ドデカンが $17.4 \mu$ $\mathrm{g} / \mathrm{m}^{2} \cdot \mathrm{h}$ 、テトラデカン酸が $5.6 \mu \mathrm{g} / \mathrm{m}^{2} \cdot \mathrm{h}$ の発生量を示すが、36時間 後では初期に比べて約10倍以上低い值となる。これは石高ボードに おいても同様であり、発生量は初期に最も高く、時間が経過するに つれて減衰していく。

そこで発生量の減衰とVOC沸点の関係について検討した。図4は 実験開始直後と36時間後の発生量比を、図 5 は実験開始36時間後の 発生量を示す。発生量がほぼ定常に達した36時間後では発生量は低 く、沸点の高低による発生量の違いはみられない。一方、発生量の 減衰についてみると、同じ建材から発生したVOCでも各物質が持つ 沸点の違いによって発生量の減衰に差がみられ、沸点が低く揮発し

\begin{tabular}{|c|c|c|c|c|c|}
\hline \multirow{3}{*}{ 物質 } & \multicolumn{5}{|c|}{ 初期発生量 $\left[\mu \mathrm{g} / \mathrm{m}^{2} \cdot \mathrm{h}\right]$} \\
\hline & \multicolumn{3}{|c|}{ ビニール壁紙 } & \multicolumn{2}{|c|}{ 石こうホード } \\
\hline & $\bar{A}$ & \begin{tabular}{|l|l}
$\mathrm{B}$ & \\
\end{tabular} & $\mathrm{C}$ & $\mathrm{A}$ & $\mathrm{B}$ \\
\hline nonanal & N.D. & 5.6 & 17.4 & N.D. & N.D. \\
\hline ethylbenzene & N.D. & N.D. & 27.9 & N.D. & N.D. \\
\hline p-xylene & N.D. & N.D. & 23.1 & N.D. & N.D. \\
\hline m-xylene & N.D. & N.D. & 17.2 & N.D. & N.D. \\
\hline cyclohexanone & 8.3 & 3.0 & N.D. & N.D. & N.D. \\
\hline trimethylbenzene & N.D. & 2.0 & 4.4 & N.D. & N.D. \\
\hline dichlorobenzene & 6.3 & N.D. & 255.2 & N.D. & N.D. \\
\hline dodecane & 8.3 & 2.9 & 4.2 & 63.4 & 87.6 \\
\hline tetradecanoic acid & 4.7 & N.D. & N.D. & 13.5 & 22.0 \\
\hline tetradecane & N.D. & 1.8 & 9.8 & 11.7 & 19.0 \\
\hline pentadecane & N.D. & N.D. & 5.9 & N.D. & N.D. \\
\hline hexadecane & N.D. & N.D. & 2.9 & N.D. & N.D. \\
\hline TVOC & 573.1 & 203.3 & 481.5 & 608.9 & 64.4 \\
\hline
\end{tabular}
やすい物質ほど発生量が大きく減衰した。以上により、建材から発 生するVOCは時間が経過するにつれて発生量が減衰するが、その減
表 3 建材からの発生ガスと初期発生量

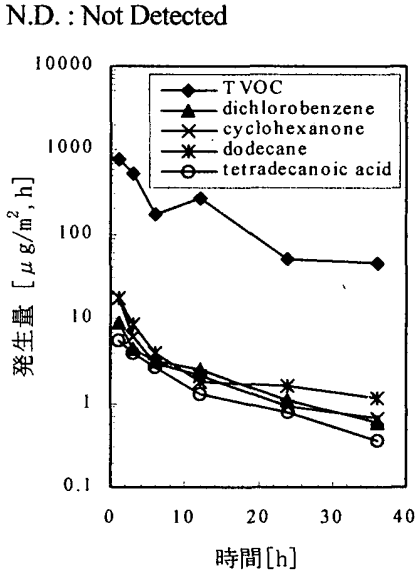

(a)ビニール壁紙A

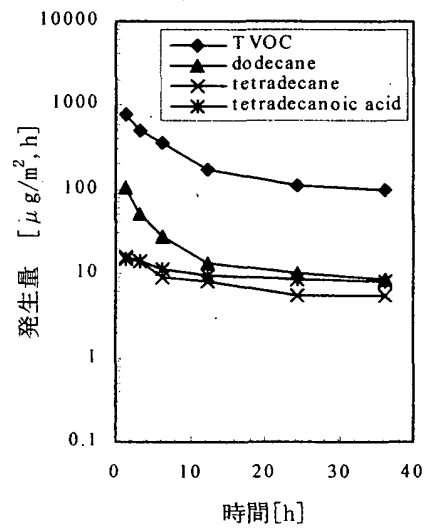

(b)石塾ボードA
図 3 発生量の経時変化

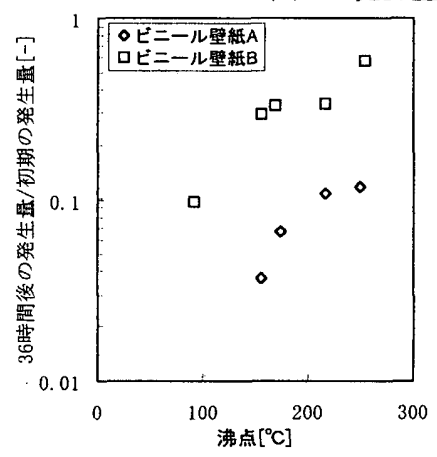

(a)ビニール壁紙

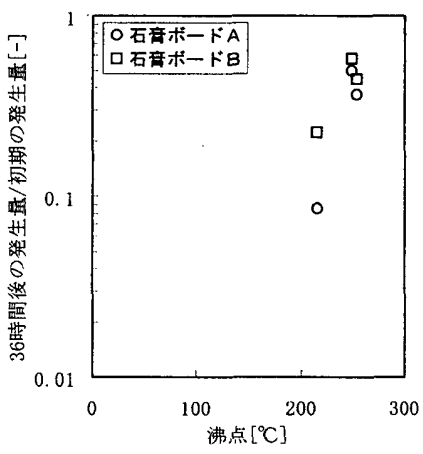

(b) 石膏ボード
図 4 発生量の減衰とVOC沸点の関係

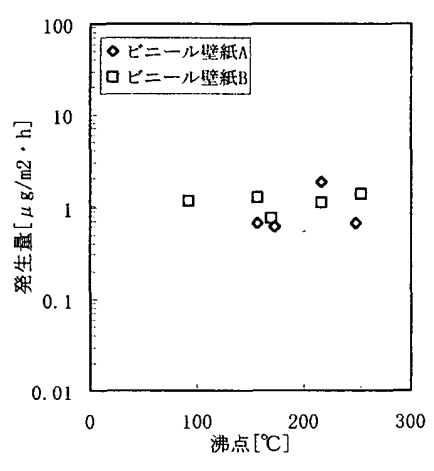

(c)ビニール壁紙A

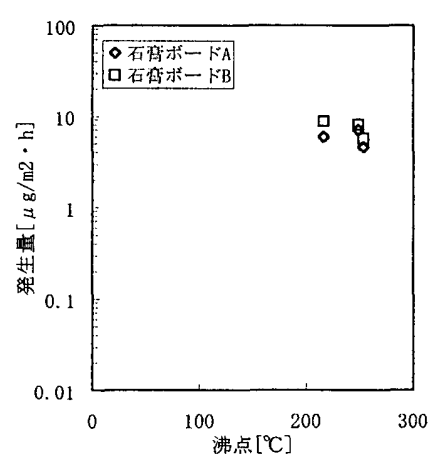

（d）ビニール壁紙B
図 5 実験36時間後の発生量とVOC沸点の関係 
衰傾向は物質によって異なることが示された。

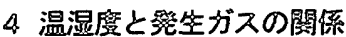

\section{1 温黁と発生量}

建材からの発生ガスを境膜搪散と建材内部の拡散または蒸散によ る現象とすれば、その発生ガスは温度、湿度、気流など様々な環境 条件の影響を受けると考えられる。そこで温湿度と発生ガスの関係 を把握するためにビニール壁紙Cと石亪ボードAを対象に温湿度実 験を行った。実験では表 2 に示したように温度については20,30， $40^{\circ} \mathrm{C}$ 、相対湿度については50,60,70\%の条件で発生ガス測定を行った。 図 6 は各温度条件におけるTVOC発生量の経時変化を示す。 TVOC発生量は前節と同様に(3) 式より求めた。ビニール壁紙Cにつ いてみると、実験開始 1 時間後のTVOC発生量は温度 $20^{\circ} \mathrm{C} て ゙ 429.0 \mu$ $\mathrm{g} / \mathrm{m}^{2} \cdot \mathrm{h} 、 30^{\circ} \mathrm{C}$ で $1951.2 \mu \mathrm{g} / \mathrm{m}^{2} \cdot \mathrm{h} 、 40^{\circ} \mathrm{C}$ で $4903.7 \mu \mathrm{g} / \mathrm{m}^{2}$ ・hなどチャン バ一の温度が高くなるにつれて発生量は大きく増加する。しかし、 実験開始 12 時間以後では温度による発生量差は小さくなる。石育 ボードAにおいても発生量が定常状態に達するまでの時間には差が あるが、発生量が定常状態に近づくにつれて温度上昇による発生量 への影響は小さくなる。

次に温度条件と発生量の関係を図 $7 、 8$ に示す。時閒経過によっ て温度の発生量への影響に差がみられることから、図 7 は実験開始 1時間後の発生量を、図 8 は実験開始24時間後の発生量を示す。ま ず実験開始1時間後の発生量についてみると、ビニール壁紙Cでは

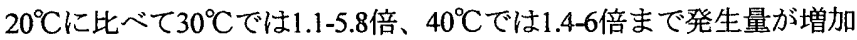
した。各物質についてみると、ビニール壁紙Cではエチルベンゼン、 キシレン、ジクロロベンゼン、石育ボードAではドデカンなど各建

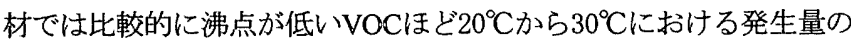
増加が大きい。一方、沸点が高い物質では低温よりも $30^{\circ} \mathrm{C} か ら 40^{\circ} \mathrm{C}$ で発生量が大きく増加する傾向を示した。

発生量がほぼ定常状態に達した実験開始24時間後では、温度によ る発生量の増加は小さく、発生量増加における低沸点物質と高沸点 物質の違いはみられなかった。各建材ではVOCの発生量がほぼ同程 度に増加した。以上により、温度の発生ガス促進効果は発生ガスの 初期に最も大きく、VOCが持つ沸点によってもその効果に差がある ことが示唆された。

図 9 は発生量の増加率と温度の関係を示す。発生量の増加率は実 験開始 24 時間後の発生量を用い、温度 $20^{\circ} \mathrm{C}$ における発生量を基準に 求めた。TVOC発生量の増加率は温度と指数的関係を示すが、その 増加傾向は各建材によって異なる。また、ビニ一ル壁紙と石㤫ボー ドから発生した同じVOCであっても、発生量の増加率は建材によっ て異なる。

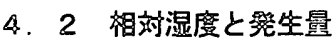

各相対湿度条件におけるTVOC発生量の経時変化を図 10 に示す。 温度と同様にチャンバー内の相対湿度が高くなるにつれてTVOC発 生量は大きく増加する。温度の場合、発生量が定常に近づくにつれ て発生量への影響は小さくなったが、相対湿度の場合、実験開始 12 時間以降になっても発生量に大きな差がみられる。

ビニール壁紙Cで発生したVOCと相対湿度の関係を図 11 に示す。 発生量は相対湿度により約1.3-11.9倍まで高くなり、温度による発生

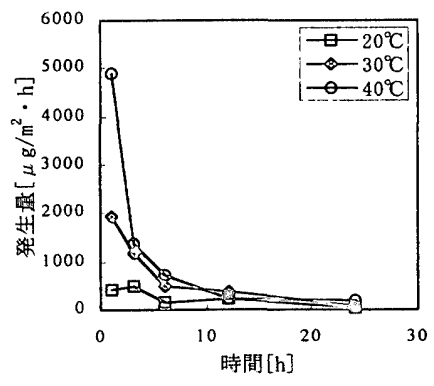

（a）ビニール壁紙 C

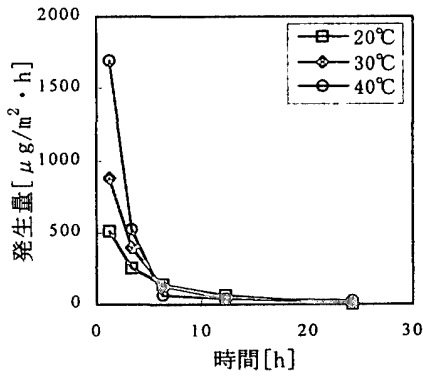

(b) 石㠇ボードA
図 6 各温度条件におけるTVOC発生量の経時変化

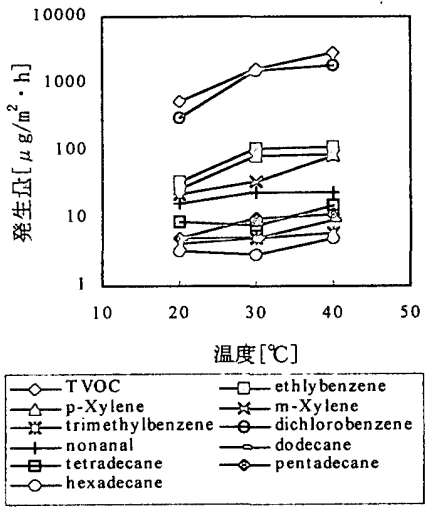

(a)ビニール壁紙C

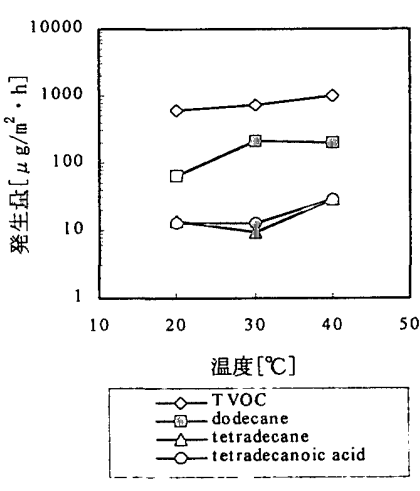

(b) 石亮ボードA
図 7 実験開始1時間後の発生量と温度の関係

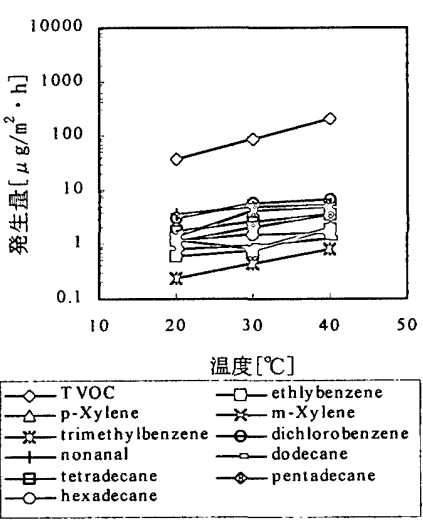

(a)ビニール壁紙C

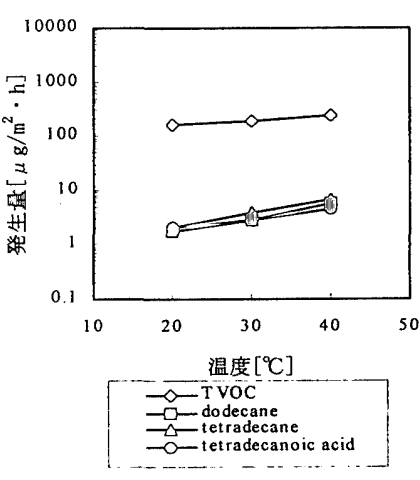

(b) 石喼ボードA
図 8 実験開始24時間後の発生量と温度の関係

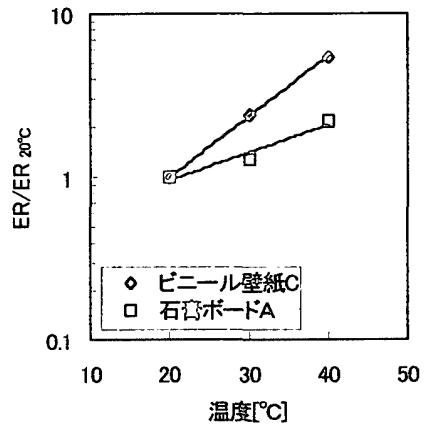

(a) TVOC

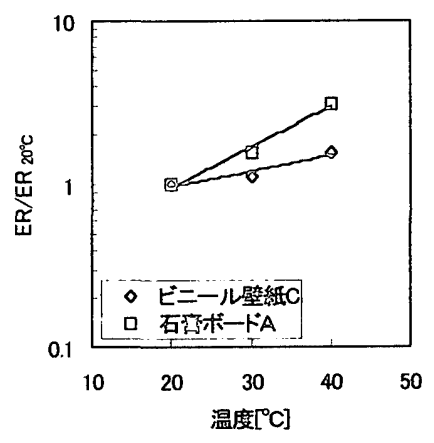

(b) ドデカン
図 9 発生量の増加率と温度の関係 
量の増加率よりも大きい值を示した。また、温度の場合、VOCの沸 点によって発生量の増加率に差がみられたことに対し、相対湿度で はVOCによる違いはみられなく、相対湿度が高くなるにつれて全て のVOCがほぼ同程度に増加する。温度による発生ガスへの影響につ いては、建材におけるVOCの拡散または蒸散が温度によって促進さ れることがその原因であると考えられるが、湿度による発生ガス促 進については今後、厳密な検討が必要であると考えられる。

温湿度と発生量の関係をまとめて図 12 に示す。ここでは実験開 始24時間後の発生量を用いた。ビニール壁紙と石膏ボードのTVOC 発生量はチャンバーの温湿度条件について指数的関係を示すが、 ビニール壁紙では湿度が、石㙜ボードでは温度による発生ガス への影響が大きくみられるなど、温度と湿度の相互作用による 発生量への影響は各建材によって異なることが示された。

\section{5 チャンパー条件と発生ガスの関係}

チャンバー実験による発生ガス評価においてはチャンバーの環境 条件に注意する必要があり、換気と試験体の表面積はチャンバー内 VOC濃度と発生量を決める基本的因子である。そこで、換気とロー ディングファクターによる発生ガスへの影響を把握するため、ビ ニール壁紙A、Bと石亮ボードBを対象に発生ガス測定を行った。実 験条件は表 2 に示したように換気回数を2、4、6回/h、ローディン グファクターを $3.55,7.10 \mathrm{~m}^{-1}$ (石高ボードの場合、 $0.71,1.42 \mathrm{~m}^{-1}$ ) と

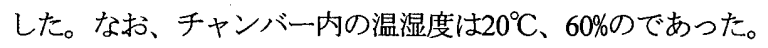

図 13 は各換気条件におけるTVOCのチャンバー濃度と発生量を 示す。チャンバー中の発生ガスは換気によって外一排出されるため、 換気回数が大きいほどTVOCの濃度は低くなる。しかし、発生量に ついてみると、実験開始3時間後からは换気による発生量の差がみ られ、36時間後の発生量は換気回数 2 回で $37.2 \mu \mathrm{g} / \mathrm{m}^{2} \cdot \mathrm{h} 、 4$ 回で44.6 $\mu \mathrm{g} / \mathrm{m}^{2} \cdot \mathrm{h} 、 6$ 回で $68.4 \mu \mathrm{g} / \mathrm{m}^{2} \cdot \mathrm{h}$ など、チャンバーの換気回数が大き くなるほど、VOCの発生量は大きく増加した。実験開始直後には換 気回数が大きいほうで発生量は低くなっているが、その原因につい ては今後、検討する必要があると考えられる。

図 14 はビニール壁紙と石高ボードにおける換気回数と発生量の 関係を示す。ビニール壁紙ではトリメチルベンゼンが約1.2-1.6倍、 ドデカンが約1.1-1.7倍など、換気回数が大きくなるにつれてVOCの 発生量はほぼ同程度に増加する。これは石高ボードにおいても同様 であり、換気回数により約1.1-1.8倍の発生量の增加がみられた。こ れより、チャンバーの換気回数が発生ガスに寄与していることは明 らかであり、チャンバー実験により発生ガスを評価する際には換気 の效果を十分考慮する必要があると考えられる。

図 15 はビニール壁紙Aに拈けるローディングファクターと TVOCの関係を示す。まず、チャンバーの濃度についてみると、 試験体の面積が大きい方でチャンバーのTVOC濃度は高く、ロー ディングファクターが7. $10 \mathrm{~m}^{-1}$ では $3.65 \mathrm{~m}^{-1} よ り も$ 約 2 倍高い值を示 す。チャンバーのTVOC濃度より求めた発生量ではローディング ファクターが小さい方で発生量が若干大きくなるが、実験開始 24 時 閒以後ではその差はみられなくなる。これは、実験条件であった 3.55、7.10 $\mathrm{m}^{-1}$ (石高ボードの場合、 $0.71,1.42 \mathrm{~m}^{-1}$ )のローディング ファクター条件では換気条件のようにチャンバー内のVOC濃度に大 きな差は得られなく、また、実験開始24時間以後では実験条件によ

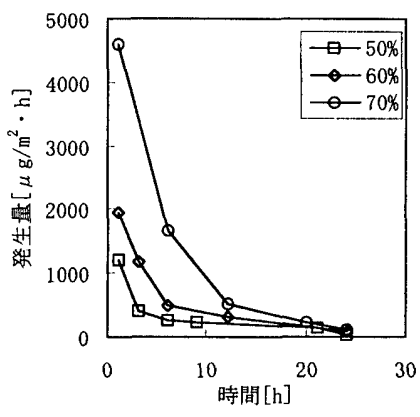

(a)ビニール壁紙C

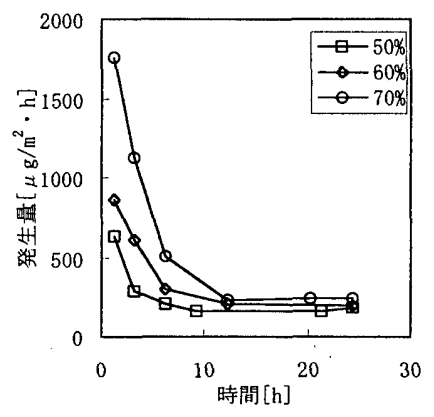

(b) 石育ボードA
図 10 各相対湿度条件におけるTVOC発生量の経時変化
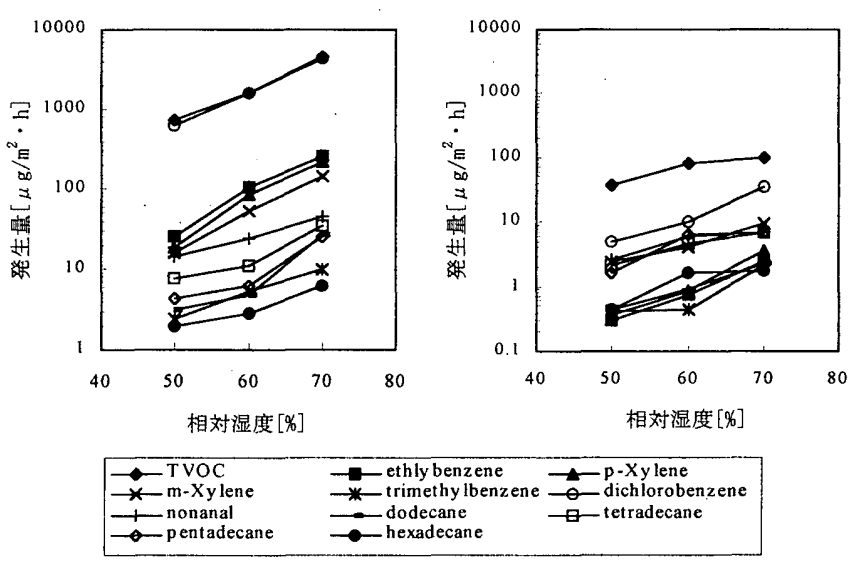

(a) 実験開始1時間後の発生量 （b）実験開始1時間後の発生量 図 11 ビニール壁紙Cにおける湿度と発生速度の関係

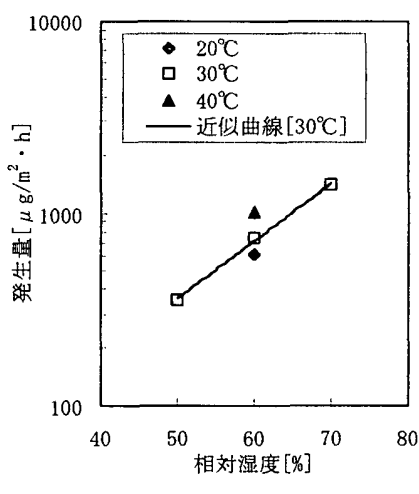

(a)ビニール壁紙C

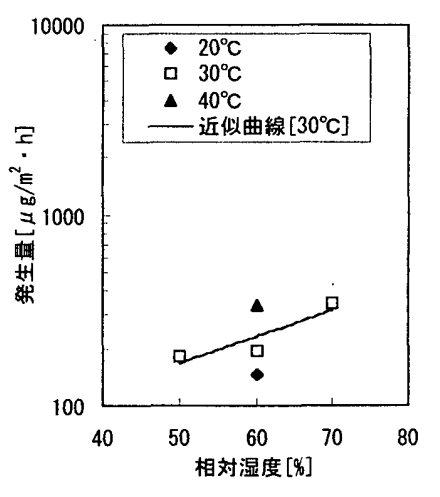

(b) 石裔ボードA
図 12 温湿度とTVOC発生量の関係

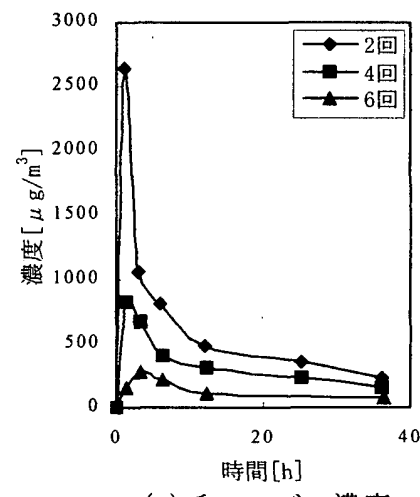

(a) チャンバー濃度

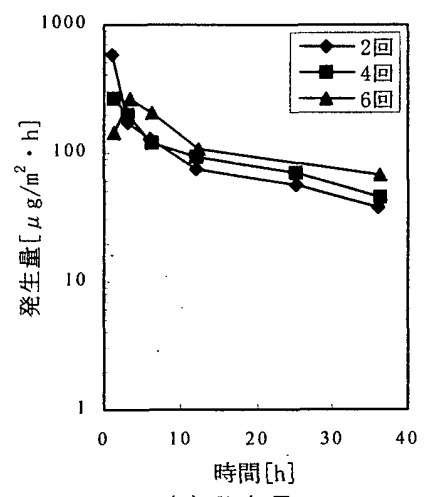

(b) 発生量
図 13 ビニール壁紙Bに㧍ける換気回数とTVOCの関係 
るチャンバー内VOC潛度差が数十 $\mu \mathrm{g} / \mathrm{m}^{3}$ 程度まで低くなったためで あると考えられる。

\section{6. まと的}

本研究では、一般建築空間でよく使われる 3 種類のビニール壁紙 と 2 種頑の石亮ボードを対象に発生ガス実験を行い、環境条件によ る発生ガスへの影響について検討を行った。本研究で得られた結果 を以下にまとめる。

（1）実験対象建材からは芳香族と炭化水素、カルボン酸などのVOC が発生し、TVOC初期発生量は64.4-608.9 $\mu \mathrm{g} / \mathrm{m}^{2}$ 。hであった。各建 材からの発生ガスは初期に最も高く、時間の経過に伴って減少する 傾向であった。建材からの発生ガスは温度が高くなるにつれてその 発生量が大きく増加することが確認された。

（2）同じ建材から発生したVOCでも各物質が持つ沸点によって発生 量の減衰に差がみられ、沸点が低く揮発しやすい物質ほど発生量が 大きく減衰することが示された。温度の発生ガス促進効果は発生ガ スの初期に最も大きく、VOCが持つ沸点によってもその効果に差が あることが示唆された。

（3）相対湿度により建材からの発生ガスは約1.3-11.9倍まで高くな り、温度による発生量の増加率よりも大きい値を示した。温度の場 合、Vocの沸点によって発生量の増加率に差がみられたが、相対湿 度ではVOCよる違いはみられなく、相対湿度が高くなるにつれて全 てのVOCがほぼ同程度に増加した。TVOC発生量は温湿度条件につ いて指数的関係を示すが、温度と湿度の相互作用による発生量への 影響は各建材によって異なった。

（4）チャンバ一の換気回数が大きくなるにつれて各建材ではVOC発 生量が約1.1-1.8倍増加し、チャンバーの換気回数が発生ガスに寄与 していることは明らかになった。ローディングファクターが小さい 方で初期におけるVOCの発生量は若干大きくなったが、実験開始 24 時間以後ではその差はみられなくなった。これは、今回の実験条件 であった3.55、7.10 $\mathrm{m}^{-1}$ (石简ボードの場合、0.71， $1.42 \mathrm{~m}^{-1}$ )のロー ディングファクター条件ではチャンバー内のVOC濃度に大きな差は 得られなく、また、実験開始24時間以後では実験条件によるチャン バ一内VOC浱度差が数十 $\mu \mathrm{g} / \mathrm{m}^{3}$ 程度まで低くなったためであると考 えられる。

本研究では、個々の建材素材に限定して実験を行ったが、建築材 料からの発生ガスは施工方法によっても大きな影響を受けると考え られる。今後は、その施工方法を考慮し、各種建材からの発生ガス に関するデータの蓄積を進めると共に発生ガスの定量的な評価方法 に関する検討を行う予定である。

\section{参考文献}

1) 藤井ら、揮発性有機化合物による室内空気質に関する実測調查、 日本建築学会計画系論文集、第500号、pp. 65-70、1997 2)朴ら、住宅における揮発性有機化合物と建材からの発生ガスによ る影響に関する実測調查、日本建築学会計画系論文集、第509号、 pp. 27-32、1998

3)Molhave L., Evaluations of VOC emissions from materials and

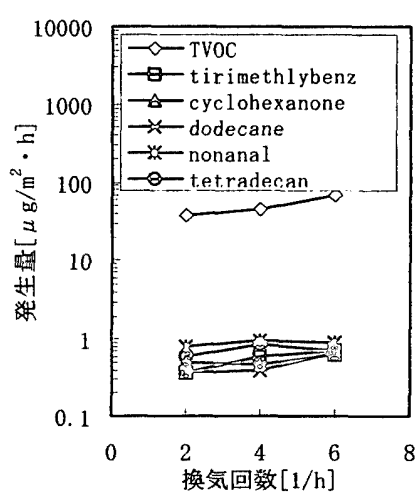

（a）ビニール壁紙 B

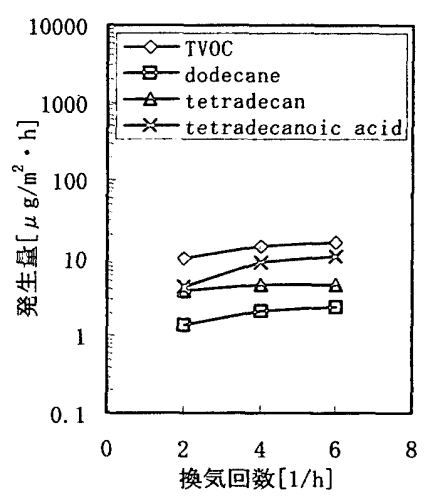

(b) 石仿ボードB
図 14 実験36時間後の発生量と換気回数の関係

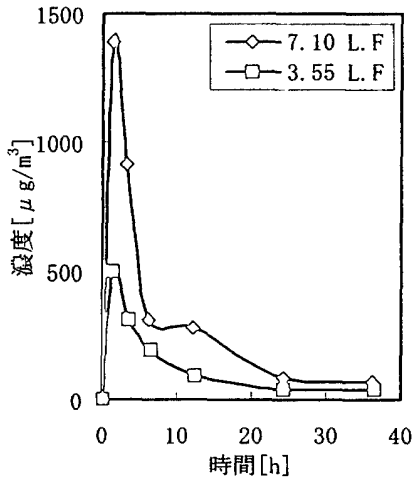

(a)チャンバー濃度

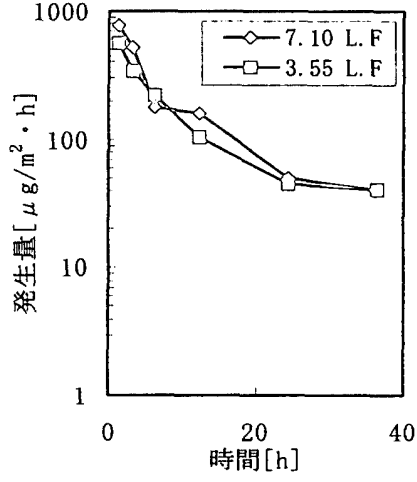

（b）発生速度
図 15 ローディングファクターとTVOCの関係

products: Solid flooring materials, Proceedings of Healthy Buildings, Vol. 1, pp.145-162、1995

4) Nielsen $P$., The Importance of Building Materials and Building Construction to Sick Building Syndrome, proceedings of Healthy Buildings'88, Vol.3, pp257-261、1988

5)Wolkoff P., A New Approach to Label The Emission of VOCs from Building Products, Part I, II, IIl, proceeding of Healthy Building, Vol.2, pp.887-904、1995

6)Dunn J.E, Models and Statistical Methods for Gaseous Emissions Testing of finite Sources in Well mixed chamber, Atmospheric Environment, Vol. 21,1987

7)Tichenor B.A, Indoor Air Sources: Using Small Environmental Test chambers to Characterize Organic Emissions from Indoor Materials and Products, USEPA Report 600/8-89-074, U.S. Environmental Protection Agency, Washington DC, 1989

8)鈴木ら、クリーンルーム内装材の発ガス評価、第14回空気清浄と コンタミネーソンコントロール研究大会、pp1-4、1996

9)鈴木ら,クリーンルーム構成材からの脱ガスの抑制に関する研究、 第15回空気清浄とコンタミネーソンコントロール研究大会、pp9-12、 1997

10)池田ら、新築及び既築集合住宅の室内空気質測定、その 3、VOC 測定結果、日本建築学会大会学術講演梗概集、pp.755-756、1997 